\title{
Water vapor release from biomass combustion
}

\author{
R. S. Parmar ${ }^{1}$, M. Welling ${ }^{1}$, M. O. Andreae ${ }^{1}$, and G. Helas ${ }^{1, *}$ \\ ${ }^{1}$ Max Planck Institute for Chemistry, Biogeochemistry Department, P.O. Box 3060, 55020 Mainz, Germany \\ *now at: IIMT Engineering College, Department of Applied Science, Meerut 250001 (UP), India
}

Received: 25 January 2008 - Published in Atmos. Chem. Phys. Discuss.: 4 March 2008

Revised: 13 August 2008 - Accepted: 8 September 2008 - Published: 22 October 2008

\begin{abstract}
We report on the emission of water vapor from biomass combustion. Concurrent measurements of carbon monoxide and carbon dioxide are used to scale the concentrations of water vapor found, and are referenced to carbon in the biomass. The investigated fuel types include hardwood (oak and African musasa), softwood (pine and spruce, partly with green needles), and African savanna grass. The sessionaveraged ratio of $\mathrm{H}_{2} \mathrm{O}$ to the sum of $\mathrm{CO}$ and $\mathrm{CO}_{2}$ in the emissions from 16 combustion experiments ranged from 1.2 to 3.7 , indicating the presence of water that is not chemically bound. This non-bound biomass moisture content ranged from $33 \%$ in the dry African hardwood, musasa, to $220 \%$ in fresh pine branches with needles. The moisture content from fresh biomass contributes significantly to the water vapor in biomass burning emissions, and its influence on the behavior of fire plumes and pyro-cumulus clouds needs to be evaluated.
\end{abstract}

\section{Introduction}

Water vapor production from biomass burning is generally considered to have little effect on atmospheric water vapor concentration. On a local scale, however, large open fires can trigger cloud formation and may even lead to thunderstorms (Stocks et al., 1997; Fromm et al., 2006). This is usually attributed to induced convection or pyro-convection. However, it is not clear what role water vapor released from biomass combustion plays in the atmospheric conditions above the fire (Potter, 2005; Trentmann et al., 2006; Luderer et al., 2006; Luderer, 2007; Clements et al., 2006).

Water vapor released from biomass combustion may have two different sources, (1) the production of $\mathrm{H}_{2} \mathrm{O}$ by chem-

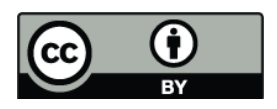

Correspondence to: G. Helas

(gth@mpch-mainz.mpg.de) ical reactions during combustion (“combustion moisture"), and (2) the release of fuel moisture that is not chemically bound to the organic molecules of the fuel. This chemically not bound water in biomass is designated as fuel moisture content, and is defined as the weight of water contained in the fuel expressed as a percentage of its oven dry weight. Dry weight, as an operational definition, is achieved, when the mass remains constant at an oven temperature of usually $105^{\circ} \mathrm{C}$. This water in the biomass would evaporate on further heating, i.e., in the course of the combustion process.

In discussing fuel moisture content, it is useful to distinguish between live and dead fuels (Chuvieco et al., 2004). The latter refer to dead grasses, foliage, twigs, branch wood, and slash. Moisture exchange in dead fuel is controlled by physical processes, i.e., dew formation, adsorption, precipitation, desorption, and evaporation. Thus the fuel moisture of dead biomass is strongly dependent on meteorological variability. In contrast, the fuel moisture content of living plants is mainly related to soil moisture and plant physiology, i.e., length of the root system, stomatal resistance, transpiration rate and others, as well as medium-term (a few days or weeks) weather conditions (Chuvieco et al., 2004). While the fuel moisture content of dead biomass usually is a few to some ten percent, the fuel moisture content of live foliage and needles easily reaches up to $200 \%$ or even more (Agee et al., 2002). Stem moisture content of more lignified material may range to above $100 \%$, as reported by Chalk and Bigg (1956) for Sitka spruce. Moisture in sugar cane stems has been reported up to $600 \%$ (Asana, 1950) and sunflower stem moisture content was measured up to $800 \%$ by Wilson et al. (1953). Although such high moisture content will inhibit direct combustion by acting as a heat sink through the evaporation of water, ignition is still possible in the end if heat transfer from the surrounding fire is large enough (Van Wagner, 1977).

Published by Copernicus Publications on behalf of the European Geosciences Union. 


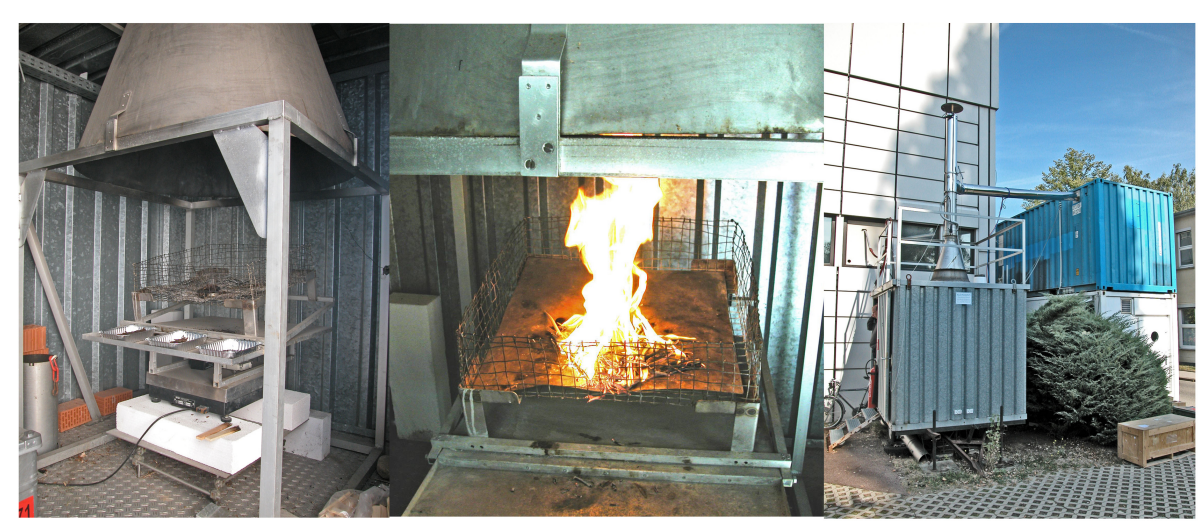

Fig. 1. Photos of the combustion facility. Left: The combustion chamber seen from the open door showing from below to top the balance, the fuel bed, and the inverted funnel. Middle: Flaming phase during a typical combustion session. Right: The combustion facility comprising of the combustion chamber outside of the building with chimney and damper valve to redirect the combustion effluents to the storage container, which is positioned above a laboratory container.

Water vapor is also formed by chemical reaction. The combustible matter of plant biomass, the solid framework, consists of celluloses and hemicelluloses (typically 50-70\% dry matter), lignin (15-35\%), proteins, amino acids, and other metabolites, including volatile substances (alcohols, aldehydes, terpenes, etc.) (Andreae and Merlet, 2001). In complete combustion, carbon dioxide and water are formed, together with other less prominent oxides such as $\mathrm{NO}_{\mathrm{x}}$. Surrogates for biomass, for instance simple sugars with the formula $\mathrm{C}_{6} \mathrm{H}_{12} \mathrm{O}_{6}$, when burned produce one molecule of water per molecule of carbon dioxide. Celluloses and condensed hexosanes $\left(\mathrm{C}_{6} \mathrm{H}_{10} \mathrm{O}_{5}\right)$ yield 0.83 and condensed pentosanes $\left(\mathrm{C}_{5} \mathrm{H}_{8} \mathrm{O}_{4}\right) 0.8 \mathrm{H}_{2} \mathrm{O}$ per $\mathrm{CO}_{2}$, while lignin, whose composition is variable but may be assumed to be close to $\mathrm{C}_{6} \mathrm{H}_{6.4} \mathrm{O}_{2}$, releases 0.53 molecules of $\mathrm{H}_{2} \mathrm{O}$ per molecule $\mathrm{CO}_{2}$. Ward (2001) uses $\mathrm{C}_{6} \mathrm{H}_{9} \mathrm{O}_{4}$ as the average for biomass (Byram, 1959) and calculates a $\mathrm{H}_{2} \mathrm{O} / \mathrm{CO}_{2}$ ratio of 0.75 . Any additional water released by a fire beyond the combustion moisture must already have been present in the fuel.

There have been recent discussions in the literature, as to whether the water vapor produced from biomass fires is essential for the formation of pyro-cumulus clouds. Potter (2005) suspected evidence of a contribution and proposed the need to determine how much moisture a fire adds to the air and whether this amount is or is not important. Trentmann et al. (2006), Luderer et al. (2006), and Luderer (2007) rejected this influence on pyro-convection on theoretical grounds in their modeling studies. They claimed that sensible heat strongly dominates over latent heat, even for high fuel moistures, so that water vapor from the fire is not important for pyro-cumulus convection. In contrast, Clements et al. (2006) presented an experimental study, from which he deduced a confirmation of Potter's (2005) argument that water vapor from a wildland or grass fire can significantly modify the dynamic environment of the lower atmosphere.
Therefore, it would be of interest to know whether combustion experiments provide constraints on the actual production of water vapor from biomass burning. Here we report on a re-analyzed data set, which originally had been produced to investigate aerosol formation from biomass combustion (Wurzler et al., 2001; Chand et al., 2004; Dusek et al., 2004; Parmar et al., 2004; Zeromskiene et al., 2004; Chand et al., 2005; Dusek et al., 2005; Hungershoefer et al., 2005; Schmid et al., 2005; Hungershoefer et al., 2008; Iinuma et al., 2007).

\section{Experimental}

The experiments were conducted in 2003 at the combustion facility of the Max Planck Institute for Chemistry, in Mainz, Germany, in the course of the Impact of Vegetation Fires on the Composition and Circulation of the Atmosphere (EFEU) campaign. It consists of a chamber for burning biomass (Lobert, 1989; Lobert et al., 1990 (Fig. 1 therein); Lobert et al., 1991 (Fig. 36.1 therein)) and a container for smoke dilution, mixing and aging, which are depicted in Fig. 1. The fires were sustained on a fuel bed housed in a container open to ambient air (Fig. 1, left). In the burning chamber (Fig. 1, middle), an inverted stainless steel funnel with an opening of $1.2 \mathrm{~m}$ diameter was positioned $0.5 \mathrm{~m}$ above the fuel bed. The smoke was lifted up via this funnel into the steel sampling container $\left(32 \mathrm{~m}^{3}\right)$ (Fig. 1, right) at a typical flow rate of about $63 \mathrm{dm}^{3} \mathrm{~s}^{-1}$ (min-max: $53.3-68.3 \mathrm{dm}^{3} \mathrm{~s}^{-1}$ ) provided by a fan at the end of the sampling line. Temperatures in the chimney were usually about $10 \mathrm{~K}$ above ambient and close to ambient in the storage container. The temperature rise is related to the rate of fuel consumption, in our experiments between 10 and $30 \mathrm{~g} \mathrm{~min}^{-1}$. The gentle updraft of approximately $5 \mathrm{~cm} \mathrm{~s}^{-1}$ at the lower end of the sampling funnel ensured that any boosting of the combustion by the induced flow was minimized. 
The sampling container (a standard 20-foot shipping container) is positioned on top of another one to avoid having to guide the effluents of the fire downwards. The fires were started by a butane torch. A damper valve in the exhaust stack above the funnel was used to vent the emissions at the beginning vertically out through the chimney, and the initial emissions were thus discarded. When combustion conditions stabilized and were self-propagating without further support, usually after a minute or so, the damper valve in the chimney was used to redirect the effluents through a steel pipe of $\sim 20 \mathrm{~cm}$ diameter and $500 \mathrm{~cm}$ length into the sampling container. Assuming turbulent flow and complete mixing, the residence time in the transfer pipe would have been $2.5 \mathrm{~s}$ and that in the container $500 \mathrm{~s}$. Ceiling fans were used to circulate and mix the sample air in the container, which served to provide sufficiently homogenized air for the measuring and sampling devices. The duration of most continuous flow experiments was about one hour.

The fuel bed was continuously weighed with a Sauter E1210 balance. The effluents in the mixing container were monitored for temperature and relative humidity by a Vaisala Humicap 133Y, while carbon monoxide and carbon dioxide were measured by Heraeus Binos NDIR systems. The temperature and humidity of air entering the combustion facility was measured with the same type of Vaisala sensor. Data acquisition was in 10-s intervals.

The air-dried European biomass fuels used were oak (Quercus spec.), pine (Pinus spec.), and spruce (Picea abies) from Germany in the form of small sticks or twigs of ten to twenty $\mathrm{cm}$ in length. Pine and spruce were also combined with dry litter from underneath the respective trees, or fresh twigs with needles of pine or spruce were combusted after starting the fires with the corresponding air-dried wood species. African biomass comprised of musasa (Brachystegia speciformis) from Zimbabwe and savanna grass (mainly Setaria flabellata, and Laudetia simplex) were mixed with small amounts of acacia (Acacia spec.) from Namibia to ensure continuous combustion. Reloading of fuel during the combustion sessions ensured that both the flaming and smoldering phases mimicked natural fires. We consider the reloading, which is done by moving fresh fuel from the sides to the center of the combustion table, as being similar to the propagation of a flame front in a wild fire. This includes that radiating heat already initiates vaporization of volatile compounds, which may boost the fire in case of light hydrocarbons, or attenuate it in case of water evaporation acting as a heat sink.

\section{Results and discussion}

The relative humidity and temperature data from 16 combustion sessions were converted to absolute humidity and expressed on a mole per mole basis for the sake of comparison to the concurrently emitted carbon species. Figures 2
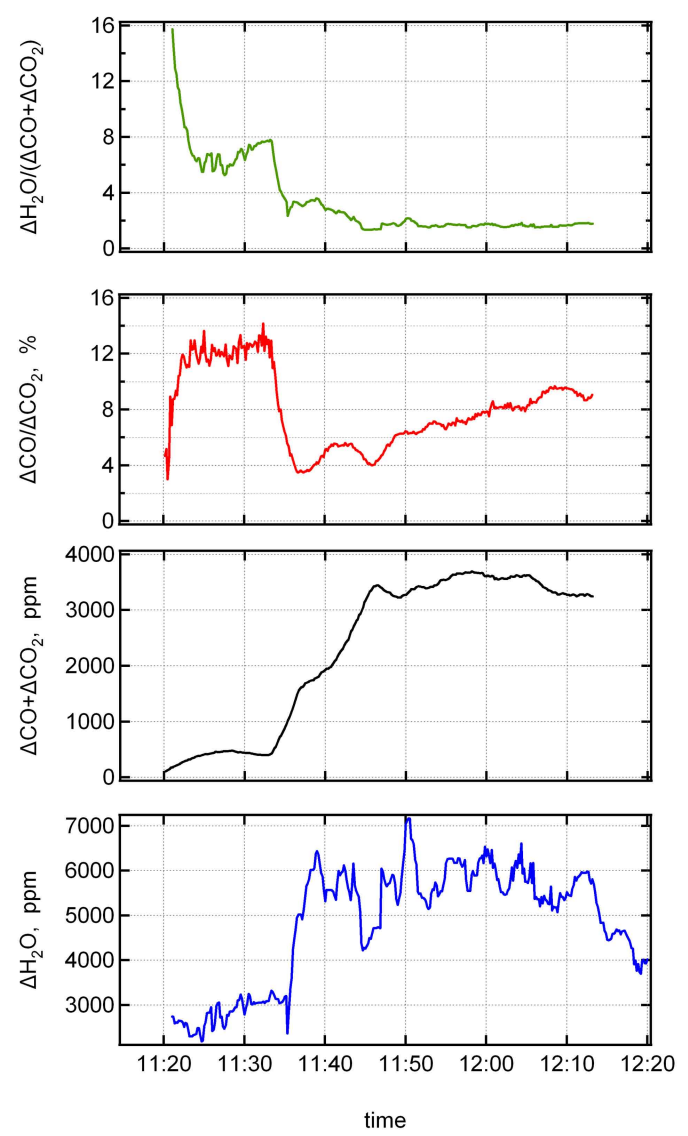

Fig. 2. Water vapor and carbon oxides released from an oak biomass fire versus time. The panels show from below: water vapor emitted in the course of the combustion session; $\mathrm{CO}$ and $\mathrm{CO}_{2}$ produced; the combustion efficiency expressed as $\Delta \mathrm{CO} / \Delta \mathrm{CO}_{2}$ (mol per mol); the emitted water vapor per emitted carbon oxides expressed as $\Delta \mathrm{H}_{2} \mathrm{O} /\left(\Delta \mathrm{CO}+\Delta \mathrm{CO}_{2}\right)$ (mol per mol).

to 4 display the measured concentrations of water vapor, the sum of carbon monoxide and carbon dioxide, and the ratios $\Delta \mathrm{CO} / \Delta \mathrm{CO}_{2}$ and $\Delta \mathrm{H}_{2} \mathrm{O} /\left(\Delta \mathrm{CO}+\Delta \mathrm{CO}_{2}\right)$ for fires in which oak, spruce with greens, and savanna grass were burned. We use the $\Delta$ (delta) notation to indicate that we subtracted the respective ambient values from the measured ones in order to express the quantity of the chemical species newly added by the fire. After the evaporation of fuel moisture, the water vapor release in the experiments was largely proportional to the carbon oxides produced.

The diagrams for the oak fire in Fig. 2 can be interpreted as follows: At the beginning of the fire, the combustion efficiency, expressed by the emission ratio of emitted $\mathrm{CO}$ over $\mathrm{CO}_{2}$, changed from 4 to $12 \%$, i.e., from a flaming toward a smoldering fire. During this time, the ratio of emitted water vapor to carbon oxides was highest, indicating that this water vapor release stemmed from the fuel moisture, and that the distillation process represented a heat sink. Once the chemically not bound water had evaporated, the emission of 

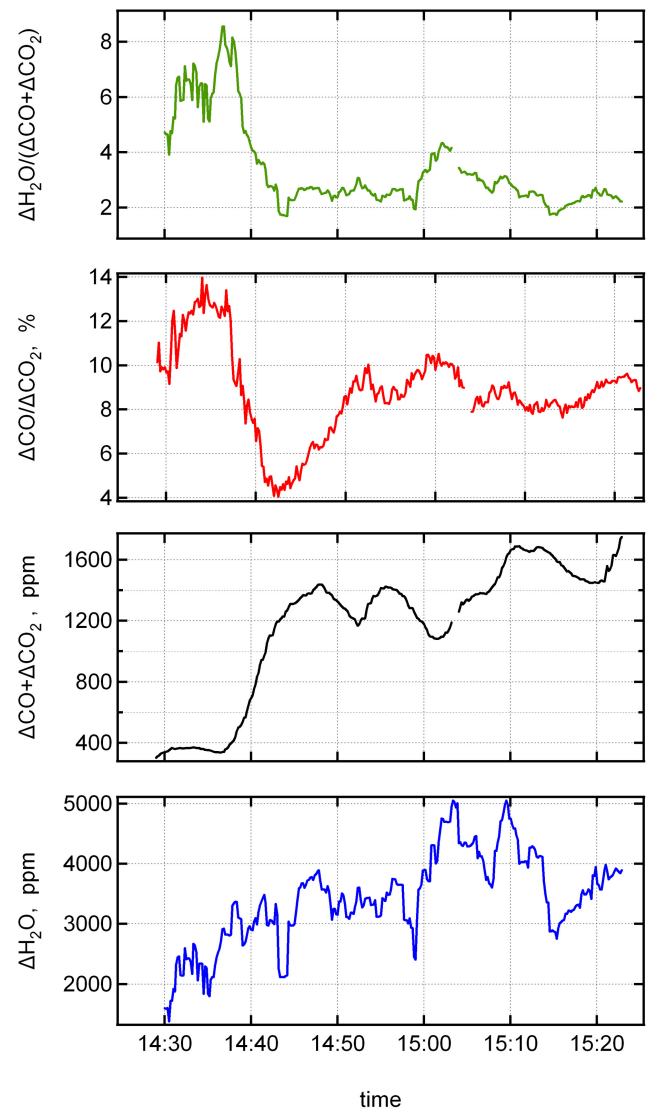

Fig. 3. Water vapor and carbon oxides released from a spruce with greens biomass fire versus time. The panels are the same as in Fig. 2.

the carbon oxides increased and the combustion efficiency rose, i.e., $\Delta \mathrm{CO} / \Delta \mathrm{CO}_{2}$ fell, indicating that the heat production was growing. In this phase, emitted water should mainly stem from the combustion process. However, the $\Delta \mathrm{H}_{2} \mathrm{O} /\left(\Delta \mathrm{CO}+\Delta \mathrm{CO}_{2}\right)$ ratio of $\sim 2$ indicates that a release of chemically not bound water was still taking place. In part, this is related to the fact that combustion of vegetation fuels is not a homogeneous process, but that different parts of the fuel bed are at different stages of combustion, so that fuel drying and pyrolysis continues in some parts of the fuel, while others are already in flaming combustion. The spruce with greens fire (Fig. 3) showed a similar behavior. For comparison, plots for savanna grass combustion are shown in Fig. 4. Note that the $\Delta \mathrm{H}_{2} \mathrm{O} /\left(\Delta \mathrm{CO}+\Delta \mathrm{CO}_{2}\right)$ ratio in this fire was smaller due to the drier fuel.

The $\Delta \mathrm{H}_{2} \mathrm{O} /\left(\Delta \mathrm{CO}+\Delta \mathrm{CO}_{2}\right)$ ratios of all measurements from the combustion sessions are combined in Table 1, as averages, in the first column. Taking into account that the water emission stems from two different processes, the corresponding median values of the individual $\Delta \mathrm{H}_{2} \mathrm{O} /\left(\Delta \mathrm{CO}+\Delta \mathrm{CO}_{2}\right)$ ratios are displayed in the second column. Interestingly, they do not differ much from the previous column. In the next two columns, maxima and minima of the individual measure-
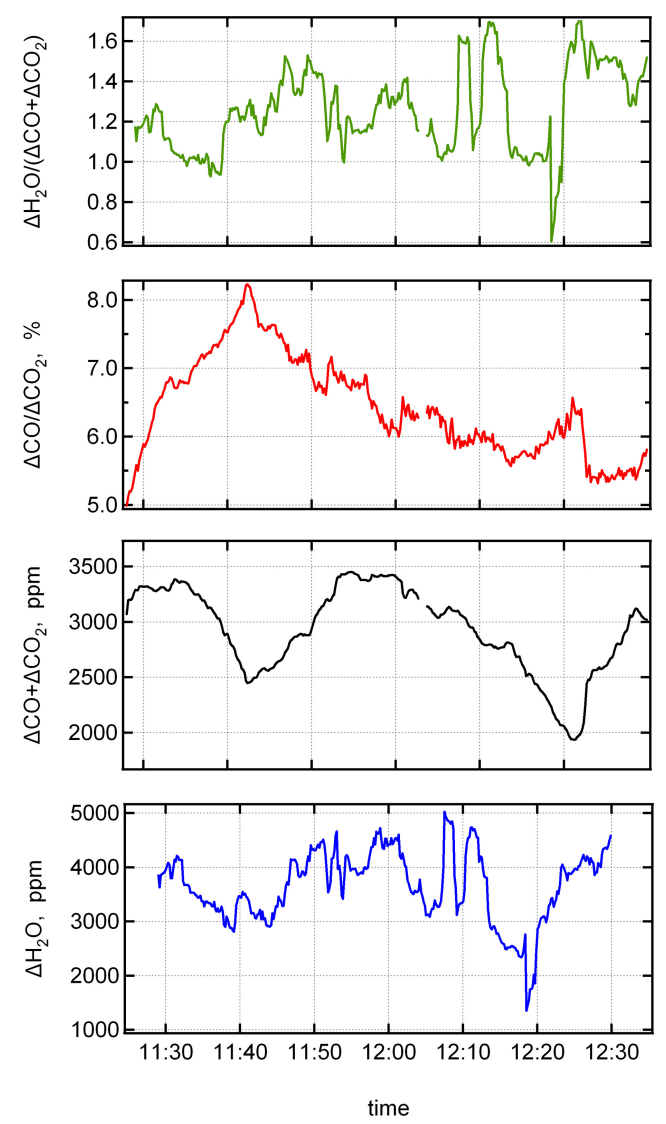

Fig. 4. Water vapor and carbon oxides released from a grass biomass fire versus time. The panels are the same as in Fig. 2.

ments are shown. Minimum values point to inhomogeneities in the emissions, whereas the maximum values, which appear mostly at the beginning of the experiments, indicate the distillation of the excess water, i.e., the fuel moisture. The integrated values are always larger than unity, pointing to a distinct contribution from fuel moisture.

We estimated the fuel moisture content by assuming a fuel composition of $\mathrm{C}_{6} \mathrm{H}_{9} \mathrm{O}_{4}$, as given by Ward (2001), which represents a typical mixture of cellulose and lignin. The ratio of possible water formation per carbon is then 0.75 ( 9 hydrogen to form 4.5 molecules of water per 6 carbon; additional oxygen comes from the atmosphere). The difference between the observed $\Delta \mathrm{H}_{2} \mathrm{O} /\left(\Delta \mathrm{CO}+\Delta \mathrm{CO}_{2}\right)$ and the value of 0.75 must be chemically not bound water, i.e., the fuel moisture, which we related to the total biomass combusted assuming a carbon fraction of 0.5 . The carbon oxides, $\mathrm{CO}$ and $\mathrm{CO}_{2}$, were assumed to form the bulk of the carbon species released during the combustion process. Their median emission ratios for the experiments are given in Table 1 for convenience.

The fuel moisture contents derived from these calculations range from 33 to $220 \%$ (Table 1). The African fuels, savanna grass and musasa, which had been stored in our laboratory for more than one year, showed fuel moisture contents below $40 \%$. An equilibration with ambient humidity may be 
Table 1. Measured $\Delta \mathrm{H}_{2} \mathrm{O} /\left(\Delta \mathrm{CO}+\Delta \mathrm{CO}_{2}\right)$ and calculated fuel moisture contents of 16 combustion sessions with different biofuels.

\begin{tabular}{|c|c|c|c|c|c|c|c|c|}
\hline \multirow[t]{2}{*}{ Fuel } & \multicolumn{4}{|c|}{ measured water to $C$ ratio } & \multicolumn{3}{|c|}{$\begin{array}{l}\text { calculated fuel moisture } \\
\text { content in \% }\end{array}$} & \multirow{2}{*}{ 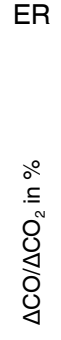 } \\
\hline & 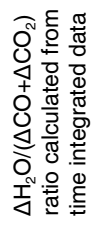 & 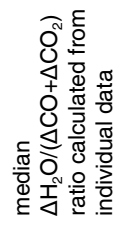 & 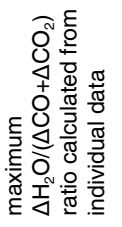 & 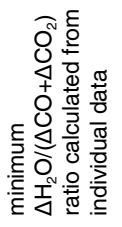 & 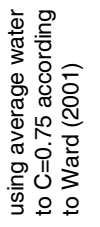 & 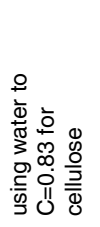 & 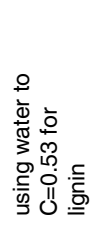 & \\
\hline oak & 2.05 & 1.80 & 15.76 & 1.33 & 98 & 92 & 114 & 7.9 \\
\hline oak & 1.51 & 1.40 & 2.13 & 1.02 & 57 & 51 & 74 & 6.6 \\
\hline musasa & 1.27 & 1.29 & 1.61 & 0.53 & 39 & 33 & 56 & 8.1 \\
\hline musasa & 1.19 & 1.17 & 1.77 & 0.63 & 33 & 27 & 50 & 9.2 \\
\hline pine & 1.42 & 1.42 & 3.12 & 0.55 & 50 & 44 & 67 & 8.5 \\
\hline pine with green & 3.71 & 3.52 & 4.47 & 0.25 & 222 & 216 & 239 & 4.8 \\
\hline pine with green & 1.29 & 1.31 & 1.74 & 0.71 & 41 & 35 & 57 & 6.8 \\
\hline $\begin{array}{l}\text { pine with dry } \\
\text { underbrush }\end{array}$ & 1.39 & 1.38 & 2.14 & 0.52 & 48 & 42 & 65 & 3.2 \\
\hline pine branch only & 1.96 & 1.92 & 4.59 & 0.65 & 91 & 85 & 107 & 4.4 \\
\hline pine branch only & 1.47 & 1.42 & 2.16 & 0.63 & 54 & 48 & 71 & 7.5 \\
\hline spruce & 2.36 & 2.35 & 2.91 & 1.97 & 121 & 115 & 137 & 3.5 \\
\hline spruce & 2.20 & 2.23 & 3.66 & 1.28 & 109 & 103 & 125 & 11 \\
\hline $\begin{array}{l}\text { spruce with } \\
\text { green }\end{array}$ & 2.21 & 2.20 & 4.84 & 1.66 & 110 & 104 & 126 & 4.9 \\
\hline $\begin{array}{l}\text { spruce with } \\
\text { green }\end{array}$ & 2.87 & 2.69 & 8.56 & 1.69 & 159 & 153 & 176 & 8.8 \\
\hline $\begin{array}{l}\text { spruce with } \\
\text { green }\end{array}$ & 1.49 & 1.49 & 2.8 & 0.65 & 56 & 50 & 72 & 7.7 \\
\hline savanna grass & 1.25 & 1.24 & 1.73 & 0.61 & 38 & 32 & 54 & 6.3 \\
\hline
\end{tabular}

assumed. In contrast, the fuels with fresh green needles had very high fuel moisture contents, although there was large natural variability. These fuels had been obtained from the forest 1-7 days before combustion. Two additional columns in Table 1 give estimates of fuel moisture content obtained by assuming the fuel to be composed of pure cellulose and lignin, respectively. So for instance, a fuel moisture content of $32 \%$ using the water/carbon ratio of cellulose (0.83) as the reference for savanna grass may be more appropriate than $38 \%$. Likewise for musasa, being much more lignified (0.53), the values of 56\% and 50\% may be more appropriate. The data found are within the range described above for typical biomass. At fuel moistures larger than $56 \%$, the contribution of fuel moisture to water vapor release will exceed that of combustion water, given the average chemical composition as stated above. The break-even points are $62 \%$ and $40 \%$ for cellulose and lignin, respectively.

The high moisture content of living fuels, e.g., leaves and needles, obviously contributes significantly to the water vapor in the emission plumes. It helps explain why pyrocumulus clouds over fires of living fuels, e.g., sugar cane, are optically quite dense in spite of low ambient atmospheric water content (Andreae et al., 1996). In their modeling study on pyro-cumulus clouds, Trentmann et al. (2006) used an average fuel moisture content of $40 \%$. This is a value more typical for dead biomass, and may be unrealistically low for wildfires. Indeed, in most of our experiments, this value was exceeded. Much higher fuel moisture contents of 70 to 200\% for instance are given for crown fires by Van Wagner (1977). Moisture in the litter layer may exceed 200\% (de Ronde et al., 1990), and combustion of such fuels will contribute to the effluents of the burns. As demonstrated by our results, where reloading of fuel during the combustion session imitates a progressing fire line, higher fuel moisture contents obviously can be attained.

The specific form in which the fuel moisture is held in the fuel remains unclear. The individual 10 -s data yield $\Delta \mathrm{H}_{2} \mathrm{O} /\left(\Delta \mathrm{CO}+\Delta \mathrm{CO}_{2}\right)$ ratios above 0.75 most of the time, indicating a continuous water release from available reservoirs. This water seems to have been released when the solid structure of the biomass was disrupted by the combustion. Only during this phase of combustion was there a correlation 
between the release of carbon oxides and water vapor. This would suggest that the water was coming from inside the cells, i.e., the vacuoles. If this were the case, the standard procedure for determining fuel moisture content by heating until weight constancy is achieved may result in underestimation, as the physical structure of the biomass remains intact. In our experiments, the fuel moisture content of the fresh biomass samples was not determined by the standard procedure, as this was not part of the original objectives of the EFEU experiment. Determining the fuel moisture content of such inhomogeneous fuels, i.e., twigs, branches, leaves etc. would only have given a rough estimate, anyway, as the fuel could not have been prepared in exact duplicate batches.

As a limitation in our data, we have to keep in mind that carbon monoxide and carbon dioxide are not the only carbon compounds emitted from the combustion. However, even if the fuel carbon not assessed as $\mathrm{CO}$ and $\mathrm{CO}_{2}$ and thus escaping in other forms as gases $(<3 \%$, Andreae and Merlet, $2001)$, aerosols $(\sim 1 \%$, Andreae and Merlet, 2001; in our experiments $\sim 3 \%$, see Iinuma et al., 2007 for details), or ash ( 1\%, Lobert, 1989) had been as high as $10 \%$, the ratio $\Delta \mathrm{H}_{2} \mathrm{O} /\left(\Delta \mathrm{CO}+\Delta \mathrm{CO}_{2}+\Delta \mathrm{C}_{\text {additional }}\right)$ would still remain above unity, and the estimated fuel moisture contents would only be reduced by 11 to $25 \%$ depending on the assumed fuel composition, with cellulose or lignin as extreme cases.

To the best of our knowledge, only Clements et al. (2006) reported on concurrent water vapor and $\mathrm{CO}_{2}$ flux measurements from a grass fire. They described tethersonde measurements showing potential temperature and water vapor mixing ratio changes at heights between 15 and $25 \mathrm{~m}$ above the fire, and deduced fluxes of the same parameters from tower measurements at 3,22, and $32 \mathrm{~m}$ height. Their measurements show a temporal and local increase of water vapor of roughly $30 \%$ above ambient in the plume close to the ground. They cautiously discussed the problem of attributing the water vapor sources as being from the fire, advection, or soil moisture. Unfortunately, their data set is only given in condensed form as average values of $\Delta \mathrm{H}_{2} \mathrm{O}$ of $3510 \mathrm{ppm}\left(2.18 \mathrm{~g} \mathrm{~kg}^{-1}\right)$ and $\Delta \mathrm{CO}_{2}$ of $2182 \mathrm{ppm}$, giving a ratio of 1.61, larger than our $\Delta \mathrm{H}_{2} \mathrm{O} / \Delta \mathrm{CO}_{2}$ value of 1.33 for old savanna grass. A ratio lower than 1.61 would have been obtained, if $\Delta \mathrm{CO}$ had been taken into account. For an assumed $\Delta \mathrm{CO} / \Delta \mathrm{CO}_{2}$ emission ratio of $8 \%$, the amount of released water to released carbon oxides would be 1.49 , resulting in a fuel moisture content of approximately $44 \%$ with cellulose as reference. The large difference between this value and the $8 \%$ fuel moisture value stated by Clements et al. (2006) make the influence of an additional source, such as standing water and/or soil moisture, very much likely. Nevertheless, this water vapor still would have been part of the biomass burning plume, i.e., have been lofted together with the combustion emissions.

This difference is also evident in the results of Clements et al. (2006): Based on a fuel moisture content of $8 \%$, a fuel composition similar to cellulose, and an assumed $\Delta \mathrm{CO} / \Delta \mathrm{CO}_{2}$ emission ratio of $8 \%$, one would predict an in- crease of only $2240 \mathrm{ppm}$ water vapor or $1.4 \mathrm{~g} \mathrm{~kg}^{-1}$, rather than the observed increase of $2.18 \mathrm{~g} \mathrm{~kg}^{-1}$. The difference must have come from additional sources. This difference would only be evident, of course, directly at the source. The ratio of water vapor to $\mathrm{CO}_{2}$ in ambient air is so large, that the initially diagnostic ratio of $\Delta \mathrm{H}_{2} \mathrm{O} /\left(\Delta \mathrm{CO}+\Delta \mathrm{CO}_{2}\right)$ is soon obscured as the mixing ratios return close to background values.

Our results suggest that fuel moisture can make a significant contribution to the water vapor content of fire plumes, and that the low contribution from "fire moisture" to pyrocloud water proposed by Trentmann et al. (2006) and Luderer (2007) may be an underestimate, as a result of their assumed low fuel moisture content of $40 \%$. While this does not necessarily contradict their result that most of the humidity and condensed water within the cloud stems from entrained environmental air, their estimate that "fire moisture" accounts for less than $5-10 \%$ of their modeled pyro-cloud's water budget may require some upward revision. Accurate measurements on water vapor release from biomass burning under field conditions are desirable to constrain future modeling efforts.

Acknowledgements. We thank J. G. Goldammer and A. Held for providing us with biomass. We are also grateful for support by the colleagues of the "EFEU" team led by S. Wurzler and M. Simmel. This work was funded by the Max Planck Society and by the Federal Ministry of Education and Research (BMBF), Germany, under the Atmospheric Research Program 2000 (AFO2000), grant \#07ATF46(EFEU). We thank T. W. Andreae for her support in preparing the manuscript.

Edited by: V. F. McNeill

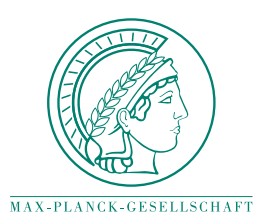

The publication of this article is financed by the Max Planck Society.

\section{References}

Agee, J. K., Wright, C. S., Williamson, N., and Huff, M. H.: Foliar moisture content of Pacific Northwest vegetation and its relation to wildland fire behavior, Forest Ecol. Manag., 167, 57-66, 2002.

Andreae, M. O. and Merlet, P.: Emission of trace gases and aerosols from biomass burning, Global Biogeochem. Cy., 15, 955-966, 2001.

Andreae, M. O., Atlas, E., Harris, G. W., Helas, G., de Kock, A., Koppmann, R., Maenhaut, W., Mano, S., Pollock, W. H., Rudolph, J., Scharffe, D., Schebeske, G., and Welling, M.: Methyl halide emissions from savanna fires in southern Africa, J. Geophys. Res., 101, 23 603-23 613, 1996.

Asana, R. D.: Growth analysis of the sugar-cane crop in North Bihar (India), Ann. Botany, N. S., 14/56, 465-486, 1950.

Byram, G. M.: Combustion of forest fuels, in: Forest Fire Control and Use, edited by: Davis, K. P., McGraw-Hill, New York, USA, 155-182, 1959. 
Chalk, L. and Bigg, J. M.: The distribution of moisture in the living stem in Sitka spruce and Douglas fir, Forestry, 29, 5-21, 1956.

Chand, D., Andreae, M. O., Zeromskiene, K., Schmid, O., Massling, A., Helas, G., Parmar, R. S., Hennig, T., Iinuma, Y., and Wiedensohler, A.: Humidity-dependent optical properties of aerosols from vegetation fires during the 'EFEU' experiment, Geophys. Res. Abstr., 6, 3892, 2004.

Chand, D., Schmid, O., Gwaze, P., Parmar, R. S., Helas, G., Zeromskiene, K., Wiedensohler, A., Massling, A., and Andreae, M. O.: Laboratory measurements of smoke optical properties from the burning of Indonesian peat and other types of biomass, Geophys. Res. Lett., 32, L12819, doi:10.1029/2005GL022678, 2005.

Chuvieco, E., Aguado, I., and Dimitrakopoulos, A. P.: Conversion of fuel moisture content values to ignition potential for integrated fire danger assessment, Can. J. For. Res., 34, 2284-2293, 2004.

Clements, C. B., Potter, B. E., and Zhong, S.: In situ measurements of water vapor, heat, and $\mathrm{CO}_{2}$ fluxes within a prescribed grass fire, Int. J. Wildland Fire, 15, 299-306, 2006.

de Ronde, C., Goldammer, J. G., Wade, D. D., and Soares, R.: Prescribed burning in industrial pine plantations, in: Fire in the tropical biota. Ecosystem processes and global challenges, edited by: Goldammer, J. G., Ecological Studies 84, Springer-Verlag, Berlin-Heidelberg-New York, 216-272, 1990.

Dusek, U., Frank, G. P., Helas, G., Hennig, T., Iinuma, Y., Massling, A., Wiedensohler, A., Zeromskiene, K., and Andreae, M. O.: Water uptake of biomass burning aerosols at super- and subsaturated conditions, J. Aerosol Sci., 35, S11-S12, 2004.

Dusek, U., Frank, G. P., Helas, G., Iinuma, Y., Zeromskiene, K., Gwaze, P., Hennig, T., Massling, A., Schmid, O., Herrmann, H., Wiedensohler, A., and Andreae, M. O.: 'Missing' cloud condensation nuclei in peat smoke, Geophys. Res. Lett., 32, L11802, doi:10.1029//2005GL022473, 2005.

Fromm, M., Tupper, A., Rosenfeld, D., Servranckx, R. and McRae, R.: Violent pyro-convective storm devastates Australia's capital and pollutes the stratosphere, Geophys. Res. Lett., 33, L05815, doi:10.1029/2005GL025161, 2006.

Hungershoefer, K., Zeromskiene, K., Schmid, O., Iinuma, Y., Helas, G., Parmar, R. S., Andreae, M. O., Herrmann, H., Wiedensohler, A., Trentmann, J., and Trautmann, T.: Comparison of modeled and measured optical properties of fresh biomass burning aerosols from various fuel types, J. Aerosol Sci., 36, p. S120, 2005.

Hungershoefer, K., Zeromskiene, K., Iinuma, Y., Helas, G., Trentmann, J., Trautmann, T., Parmar, R. S., Wiedensohler, A., Andreae, M. O., and Schmid, O.: Modelling the optical properties of fresh biomass burning aerosol produced in a smoke chamber: results from the EFEU campaign, Atmos. Chem. Phys., 8, $3427-$ 3439, 2008,

http://www.atmos-chem-phys.net/8/3427/2008/.

Iinuma, Y., Brüggemann, E., Gnauk, T., Müller, K., Andreae, M. O., Helas, G., Parmar, R., and Herrmann, H.: Source characterization of biomass burning particles: The combustion of selected European conifers, African hardwood, savanna grass, and German and Indonesian peat, J. Geophys. Res., 112, D08209, doi:10.1029/2006JD007120, 2007.

Lobert, J. M.: Verbrennung pflanzlicher Biomasse als Quelle atmosphärischer Spurengase: Cyanoverbindungen, $\mathrm{CO}, \mathrm{CO}_{2}$ und $\mathrm{NO}_{\mathrm{x}}, \mathrm{PhD}$ thesis, Mainz, 1989.

Lobert, J. M., Scharffe, D. H., Hao, W. M., and Crutzen, P. J.:
Importance of biomass burning in the atmospheric budgets of nitrogen-containing gases, Nature, 364, 552-554, 1990.

Lobert, J. M., Scharffe, D. H., Hao, W.-M., Kuhlbusch, T. A., Seuwen, R., Warneck, P., and Crutzen, P. J.: Experimental evaluation of biomass burning emissions: Nitrogen and carbon containing compounds, in: Global Biomass Burning, edited by: Levine, J. S., The MIT Press, Cambridge, Mass., USA, 133-142, 1991.

Luderer, G.: Modeling of deep-convective transport of forest fire smoke into the upper troposphere and lower stratosphere, $\mathrm{PhD}$ thesis, Mainz, 2007.

Luderer, G., Trentmann, J., Winterrath, T., Textor, C., Herzog, M., Graf, H. F., and Andreae, M. O.: Modeling of biomass smoke injection into the lower stratosphere by a large forest fire (Part II): sensitivity studies, Atmos. Chem. Phys., 6, 5261-5277, 2006, http://www.atmos-chem-phys.net/6/5261/2006/.

Parmar, R. S., Welling, M., Schmid, O., Chand, D., Andreae, M. O., and Helas, G.: Measurement of aerosol and trace gas emissions from vegetation fires for various fuel types and burning conditions, Geophys. Res. Abstr., 6, 04718, 2004.

Potter, B. E.: The role of released moisture in the atmospheric dynamics associated with wildland fires, Int. J. Wildland Fire, 14, 77-84, 2005.

Schmid, O., Helas, G., Iinuma, Y., Zeromskiene, K., Herrmann, H., Massling, A., Parmar, R. S., Wiedensohler, A., and Andreae, M. O.: Quantification of emissions and specific light absorption for biomass burning aerosols from various fuel types, J. Aerosol Sci., 36, p. S121, 2005.

Stocks, B. J., van Wilgen, B. W., and Trollope, W. S. W.: Fire behaviour and the dynamics of convection columns in African savannas, in: Fire in the southern African savannas -Ecological and atmospheric perspectives, edited by: Wilgen, B. W., Andreae, M. O., Goldammer, J. G., and Lindesay, J. A., Witwatersrand University Press, Johannesburg, RSA, 47-55, 1997.

Trentmann, J., Luderer, G., Winterrath, T., Fromm, M. D., Servranckx, R., Textor, C., Herzog, M., Graf, H.-F., and Andreae, M. O.: Modeling of biomass smoke injection into the lower stratosphere by a large forest fire (Part I): reference simulation, Atmos. Chem. Phys., 6, 5247-5260, 2006, http://www.atmos-chem-phys.net/6/5247/2006/.

Van Wagner, C. E.: Conditions for the start and spread of crown fire, Can. J. For. Res., 7, 23-34, 1977.

Ward, D.: Combustion chemistry and smoke, in: Forest Fires: Behavior and Ecological Effects, edited by: Johnson, E. A. and Miyanishi, K., Academic Press, San Diego, USA, 55-77, 2001.

Wilson, C. C., Boggess, W. R., and Kramer, P. J.:Diurnal fluctuations in the moisture content of some herbaceous plants, Amer. J. Botany, 40, 97-100, 1953.

Wurzler, S., Herrmann, H., Neusüß, C., Wiedensohler, A., Stratmann, F., Wilck, M., Trautmann, T., Andreae, M. O., Helas, G., Trentmann, J., Langmann, B., Graf, H., and Textor, C.: Impact of vegetation fires on the composition and circulation of the atmosphere: Introduction of the research project EFEU, J. Aerosol Sci., 32, S199-S200, 2001.

Zeromskiene, K. Wiedensohler, A., Massling, A., Schmid, O., Parmar, R. S., and, Helas, G.: Physical properties of biomass burning aerosol particles from the EFEU experiment, J. Aerosol Sci., 35, S1165-S1166, 2004. 